\title{
Relations in Virtual Education: A study on the antecedents of loyalty
}

\section{(Relaciones en Educación a Distancia: Un estudio sobre los antecedentes de lealtad)}

\author{
Marcelo Curth \\ Universidade Feevale (Brasil) \\ Cláudio Hoffmann Sampaio \\ Pontifícia Universidade Católica do Rio Grande do Sul, PUCRS (Brasil) \\ Rafael Spolavori \\ Faculdades QI (Brasil)
}

DOI: http://dx.doi.org/10.5944/ried.22.1.22219

How to reference this article:

Curth, M., Hoffmann Sampaio, C., y Spolavori, R. (2019). Relations in Virtual Education: A study on the antecedents of loyalty. RIED. Revista Iberoamericana de Educación a Distancia, 22(1), pp. 289-307. doi: http://dx.doi.org/10.5944/ ried.22.1.22219

\begin{abstract}
The aim of this paper is to understand the process of forming relationships between educational institutions and students. The virtual education market is considered to be of great importance in our society, which is in constant development and highly competitive. Thus, the reasons for the relations between the perceived quality, trust, commitment, and loyalty were analyzed. Specifically, the factors to be taken into account are trust, perceived quality, commitment, and loyalty. In this exploratory study, in-deep educational interviews were done with experts (managers/coordinators), teachers, and students. The results show that the relevant reasons for the relationship between perceived quality and loyalty were: feelings of being well received, motivation, and credibility. The following reasons were found for trust and loyalty: transparency, commitment of the client/student with the institution, reflection on learning as a result of the course, and good faith. In relation to commitment and loyalty, cognitive commitment (calculative) was highlighted as the principal reason: the changes provided by the course.
\end{abstract}

Keywords: perceived quality; trust; commitment; loyalty; virtual education. 


\section{Resumen}

El objetivo de este artículo es comprender el proceso de formación de relaciones entre las instituciones educativas y los estudiantes. El mercado de educación a distancia es considerado uno de los sectores de mayor trascendencia para nuestra sociedad, que se encuentra en constante desarrollo y es realmente competitivo. De ahí la relevancia de las relaciones con respecto a la confianza, calidad percibida, compromiso y lealtad. Por ello, se analizaron los motivos que crean las relaciones entre confianza, calidad percibida, compromiso y lealtad. Se realizó un estudio cualitativo y exploratorio, con entrevistas individuales y en profundidad con expertos (gerentes/coordinadores), docentes y estudiantes. Los resultados muestran que, para la relación entre la calidad percibida y la lealtad, las razones relevantes fueron: sensación de ser bien recibidos, motivación y credibilidad. Para la confianza y la lealtad, se encontraron como razones: transparencia, compromiso del cliente/alumno con la institución, reflejo del aprendizaje como resultado del curso y la buena fe. En la relación de compromiso y lealtad, el compromiso cognitivo (calculativo) se destacó como la razón principal: los cambios proporcionados por el curso.

Palabras clave: calidad percibida; confianza; compromiso; lealtad; educación a distancia.

In higher education institutions (HEI) context, concern with competitiveness is observed in the rise of the number of institutions. Given this context, concern with marketing is now frequent among university managers. Hence, knowing how the loyalty of the student is made becomes important in the context of higher education, thus making the process of maintaining the students already enrolled or attracting new ones even more important.

Several studies have been carried out aiming at better understanding how long-term relationships are established in different markets. Some of these studies proposed models where the formation of loyalty starts to fall under a significant influence of factors such as customer satisfaction (Taylor \& Hunter, 2003; Harris \& Goode, 2004; Aurier \& Goala, 2010), perceived quality (Aydin \& Özer, 2005; Lenka et al., 2009), commitment (Morgan \& Hunt, 1994; Garbarino \& Johnson, 1999; Wang \& Holcombe, 2010), trust (Sirdeshmukh et al., 2002; Agustin \& Singh, 2005; Ahu, 2005; Rohden et al., 2016), and perceived value (Zeithaml, 1988; Sirdeshmukh et al., 2002). Therefore, some studies have focused on the relationships between HEI and their students, specifically trying to understand the relationships among perceived quality, trust, commitment, and loyalty (Tinto, 1975; 2007; Hennig-Thurau et al., 2001; Bergamo, 2008). However, there is a lack of publications on the reasons for each relationship considering the constructs Trust, Perceived Quality, Commitment, and Loyalty in HEI with distance courses. This is the main objective of this study, in which exploratory, qualitative research was used as the method. 


\section{Theoretical Foundation}

\section{Perceived quality}

Perceived quality is an important construct of loyalty, especially in the service sector. For Anderson et al., (1994), perceived quality can be considered an assessment of the company's performance by the customers, with good performance tending to positively influence the attitudes and behavioral intentions of customers in relation to the supplier. The delivery of high-quality services is considered essential for the success and survival of the strategies in competitive environments (Dawkins \& Reichheld, 1990) because the perceived quality is understood as a function of the expected service, the perceived service, and the image of the company (Charalambou et al., 2016). Therefore, the perceived quality of the service positively influences the behavior chosen by the customer, and this will determine the continuity and the intensity of the relationship with the organization (Hennig-Thurau et al., 2001). However, perceived quality consists of an overall assessment of long-term performance (Mathmann et al., 2016).

According to Hennig-Thurau et al. (2001), the specific characteristics of the education sector, such as the high levels of involvement and cognitive skills required, make the quality perception the most appropriate to understand because it is also influenced by the customer's ability to perceive the potential benefits of a product/ service after it is acquired. Based on the issues stated above, Guimarães (2005) reports that students contribute decisively to the service and, consequently, to their own satisfaction. Therefore, one of the challenges for educational institutions is to develop a quality culture among their students.

\section{Trust}

Trust is seen, in many studies, as an essential component of successful relationships (Moorman et al., 1993), while essential for relationships is having a long-term status and, consequently, being retained is an important factor of loyalty (Garbarino \& Johnson, 1999; Kao \& Lin, 2016).

According to Grönroos (2003), trust is the expectation from one party that the other will behave in a predictable manner in a given situation. According to Semprebon and Prado (2016), trust reduces uncertainty in situations of vulnerability for the consumer. Along the same lines, Morgan and Hunt (1994) report that trust is an important factor when developing marketing relationships and only exists when one of the parties believes that the other is just and deserves credibility. These authors include the attributes of the consistency, competence, honesty, responsibility, good faith, and integrity of the partners.

In relation to the influence of trust and loyalty, Sirdeshmukh et al. (2002) point out that there is a reciprocal relationship between trust and loyalty since the 
more the company aims at the trust of the customer, the more the customer will be loyal to the company. In the educational context, the construct of trust is based on the previous experiences that each student has with professors and professionals connected with the educational process. At this point, the following topics are also addressed: perceived security topics regarding the professors when teaching a lesson, exams corresponding to what is taught in class, conferences, and lectures given by the teaching staff, along with charisma and proximity. These make trust an important predictor of loyalty (Bergamo, 2008).

\section{Commitment}

According to Morgan and Hunt (1994), commitment refers to the desire to keep a valid relation-that is, when a partner believes that the relationship is so important that the maximum effort in keeping it is justified. One issue to be highlighted is the division between the construct of commitment, conceptualized by Hennig-Thurau and Klee (1997) as the long-term customer orientation in a relationship based on emotional (affective) aspects, and the conviction that staying in the relationship will bring more benefits than terminating it (cognitive aspects).

Thus, Tinto (2007) states that emotional commitment is determined by the degree of integration that the student has with the university system and the nonuniversity system. The university system is divided into the following: a) academic system, which consists of academic activities developed in a campus, such as courses, events, academic groups, and other extracurricular activities offered by HEI; and b) the social system, which encompasses the student's socialization and intensive contact with other campus students through sports activities, interest groups, and student residences. The non-university system is related to aspects that negatively influence the customer/student's emotional commitment to the HEI (Tinto, 1975).

In cognitive commitment domain, in turn, Geyskens et al. (1996) report that the customer considers the benefits that they will receive if the relationship continues. For Wetzels et al. (1998), cognitive commitment positively influences opportunism and the search for better alternatives for the customer, thus differentiating itself from the affective approach to commitment. However, Lee et al. (2016) emphasize that service performance influences affective commitment.

According to Bergamo (2008), commitment focuses on the cost-benefit relationship between the student's persistence at the chosen university and the perception of the negative aspects related to leaving the HEI as well as the goal of graduation, focusing on the student's real desire to graduate from the HEI. Cognitive commitment is considered as related to the way the course is presented, and it is a factor that is more important than only providing essential beliefs when teaching each class. In this domain, some factors are of utmost importance: the presentation of the course as a key element for the students' reaction, the importance of a variety of techniques to effectively gain the involvement of the students, and the transmission 
of information on the procedures of the course and its forms of evaluation (Curran \& Rosen, 2007).

\section{Loyalty}

According to Oliver (1999), in the 1990s, loyalty started to be considered as a strategic tool and part of company discussions, mainly to guarantee a basis for loyal clients. By creating and maintaining customer loyalty, a company develops a longterm, mutually beneficial relationship with customers (Pan et al., 2012; Sampaio et al., 2012; Al-Dweeri et al., 2017). The construct of loyalty refers to a deep and consistent commitment in terms of the future repurchase of a product or preferred service, thus generating repeated purchases from the same brand, despite situational influences and marketing efforts to cause a change in behavior or a search for another brand (Oliver, 1999). Larán and Espinoza (2004) state that repeated purchasing cannot be considered as a synonym for loyalty because it can be related to other aspects, such as price, convenience, or event loyalty to several brands simultaneously.

In the educational context, the loyalty of the student is a key objective of private HEI, which is financially supported by the enrollment fee. Retaining the student means having a solid and predictable financial basis for the future activities of the HEI. According to Hennig-Thurau et al. (2001), loyalty results from multiple interrelated constructs. Therefore, they suggest a holistic approach to their explanation because a single construct is not sufficient to explain loyalty (Perin et al., 2012).

\section{Research Method}

To meet the objective proposed in this study, a qualitative, exploratory research method was chosen because it is the most adequate method when the need arises to understand phenomena in complex social contexts (Malhotra, 2006).

The sample included 25 respondents who agreed to participate in the research and met the established criteria. These respondents were divided as follows: experts (managers/coordinators of the institution), students (clients), and professors of the institutions.

The qualification criteria for the interviewees were the following in the case of managers of educational institutions: a) having worked for more than one year (two semesters) in the coordination of the institution; b) being registered with the country's education regulator; and c) belonging to an institution that offers distance learning courses for more than one year (two semesters).

The students/clients chosen should have the following characteristics to take part in this study: a) they were properly registered and to be in compliance with the institution; b) they had all the resources for the satisfactory development of a discipline in the distance modality (computer, broadband internet, etc.); and c) they had completed more than one discipline in the distance education modality. 
The professors who were chosen to participate in the research should present the following characteristics: a) have taught in more than one discipline in the distance education; b) have been an employee of the institution for at least one semester; and c) have had training linked to the area of the discipline (graduation, postgraduation, and master's degree).

The subjects of the research were found in nine HEI: seven of them are private and two are supported by the federal government. The distribution of the interviewees between private and federal HEI was characterized for having 17 interviewees in private institutions and eight in publish institutions.

In this study, the semi-structured model of interviews was used. The questions for the semi-structured model of the interview were divided into four blocks, each referring to the reasons for the relationships between the constructs: Perceived Quality and Loyalty, Trust and Loyalty, and Commitment and Loyalty.

The data were collected using an in-depth individual research method applying the saturation criterion to set the total number of interviews to be made with each group (Miles \& Huberman, 1994).

To transform the data collected in the research results, content analysis procedures were used to systematize, categorize, and make the analysis of the interviews possible (Yin, 2005). The procedure used for this research was the thematic codification, where the groups studied derive from the research question; thus, they were defined a priori (Flick, 2009).

\section{Results for The Reasons of The Relationships Between Perceived Quality, Trust, Commitment, and Loyalty}

\section{Perceived quality and loyalty: emotional background of the student}

According to Boulding et al. (1993), the level of sentimental attachment is higher when the perceived quality is above the target levels. Among the reasons found in the relationship between perceived quality and loyalty, the feeling of being accepted is emphasized, as shown in the reports below:

“(...) the classes in the environment must be attractive; the contact must be individualized so that the student may perceive that distance education is successful. This makes the students not feel alone, feel welcomed by the proposition of distance education, feel welcomed by all involved, embraced." (Manager 2)

The answers of the managers interviewed aligned when the need of the students to feel/be welcome is mentioned. Managers emphasized that, for the student to feel welcome, it is necessary that other actors play their roles efficiently, as is the case with professors/tutors. Such actors must, in addition to developing attractive 
lessons and virtual environments, develop strategies of activities so that students feel as though they are part of the HEI.

Similarly, the professors followed the line of thought of the managers and expressed their view that the students were welcome in the institution with distance education courses as follows:

"I believe that the institution must create activities in order to make the student feel more welcome, comfortable in the institution." (Professor 1)

Parasuraman et al. (1985) report that a large part of the services is produced and consumed at the same time and that, usually, the quality evaluation is performed during the service delivery and in the interaction between the customer and the staff of the company providing the service. Thus, it is believed that the need for interactions between the actors of the institution and the students is not only important but also that they are internalized by the involved parties, in view of the answers shown below:

"One of the factors that I saw that made me see the quality was being contacted by the course coordinators, the people who created (developed) the course (...). I felt more accepted, closer to the decision makers. Also, some requests made by the group targeted directly the coordinator in a classroom. (...)" (Student 6)

Related to the reason found in the reports of the students, those who have a greater need for affiliation demonstrate better performances when they realize that affiliation (Testa \& Luciano 2011). In this sense, the participation of the students themselves for the development of this type of relationship becomes important.

Other reason found in the three groups, which was mentioned the most by the group of professors and also related to emotional aspects of loyalty, is the motivation (stimulus), as is exemplified in the reports below:

"The quality perceived by the student regarding what the institutions offer stimulates, motivates, and makes the student persist. At the college, we were shaping the students, we improved the structure, the teaching staff, etc. In the end, the students were even more dedicated." (Manager 4)

Among the managers interviewed, only one mentioned motivation as a reason for the relationship between perceived quality and loyalty. He highlighted the importance of the institution perceiving what motivates the student in the virtual academic environment. The manager noted that the changes made in the structure and the teaching staff resulted in a bigger devotion on the part of the students. Some of the factors pointed out by the manager were also highlighted by the professors interviewed, as shown in the reports below. 
“The students' understanding of how they will 'get around' in a virtual environment, which makes them realize the quality of what he is receiving. This makes the student feel stimulated, motivated, and involved and continues with the distance education proposition. Similarly, the way the materials are made available makes the students feel stimulated." (Professor 2)

The answers found in the reports of the managers and professors are related to dealing with issues such as the type of materials used, the professors, the structure, etc. This, according to the reports, makes the students motivated about the institution and by the nature of the course; consequently, they stay in the institution. Related to this, the didactic material for distance education is a key element of building knowledge and for the maintenance of the motivation of the involved parties (Villardi \& Oliveira, 2005). However, these were not the only issues raised by the students, as shown below.

"I perceived the quality in the type of education that I was receiving when I saw that it was different from what I had seen previously (...) both in actual courses and distance courses. I stayed in the institution because I motivated myself with that (...)." (Student 2)

The responses of the students/clients do not fully converge with the responses of the other actors interviewed, with the students/guests mentioning the motivation to continue, with the results/applications that they find in everyday situations as the main reason for the perceptions of quality that lead to their loyalty to the HEI. Thus, incongruity between the responses of the actors can lead to a misplaced delivery of values by the HEI to students, which may be related to an increase of students dropping out of the distance academic environment.

Perceived quality and loyalty: credibility of the distance education from the student's side

One of the themes found in the report of the groups analyzed is related to the credibility of distance education. Therefore, it was emphasized that the practices of the institution positively influence the fact that the student believed, or not, in the distance education.

"When the students perceive quality in the course, in the institution, they credited the institution. This makes them believe in the distance education proposition and, consequently, stay until the end of the course." (Professor 1) 
"The perceived quality generates credibility. If the student perceives the structure, the professors, and the content to have quality, this student believes so." (Manager 1)

The group of professors interviewed stated that, when the student perceives quality, credibility also occurs, making the student believe in the proposition of the course. According to the reports, credibility, in the eyes of the student/customer, would be related to not viewing the agent as the individual of the communication, mainly because they never did a distance course.

Among the representatives interviewed who were managers, one emphasized that credibility is a reason for the link between perceived quality and loyalty, pointing to the structure, professors, and contents developed as principal factors. The group of managers interviewed, like the professors, emphasize the relevance of credibility not only regarding the institution but also regarding the proposition of distance education in general.

"The changes made after the requests made us (the students) develop a greater perception of the quality of the course. These changes made us even believe more in the distance education." (Student 1)

The group of students/customers also emphasized the improvements that were made. However, the improvements emphasized were not related to the issues reported by the interviewees from the other groups. They emphasized, in their reporting, the credibility given by the student/customer to the relationship between the institution and the development of this relationship.

\section{Trust and loyalty: transparency between those involved}

The relationship between trust and loyalty is explained by the reciprocity of arguments-that is, when the suppliers act so that the trust of the customer can be built, the perceived risk of the supplier of a specific service is probably reduced, enabling the customer to make reliable predictions about the future behaviors of the supplier (Sirdeshmukh et al., 2002). Thus, transparency among the parties involved is one of the reasons for the relationship between trust and loyalty that was highlighted in the reports of the groups interviewed, and it was considered by the respondents as important for the reciprocity of arguments and the perception of justice among the students to occur, as described in the reports below.

"When the student feels comfortable in the environment, in terms of interaction, they trust it more. The relationship automatically is more transparent, and I (Manager) see that this makes the student see the institution differently, and they end up staying." (Manager 8) 
The managers reported that transparency is one of the factors that make the student/customer perceive the institution differently. However, the synergy pointed out by one of the managers interviewed has, as a starting point, the management of people and the internal processes of the HEI. Thus, it is understood that the transparency necessary for the student/customer remains in the institution as it goes through managerial channels and the contact sectors, such as reception, secretaries, the coordination of courses, and professors.

"When the trust between the professor or tutor and the student occurs, the closeness is different. The relationship is more transparent. The student is more relaxed." (Professor 8)

"In the course, I feel that the communication between the students and the people that created the course is very good. We had reported things we did not like and they were readily solved. [... This] provides a greater interactivity and transparency among all those involved." (Student 5)

In the reports of the professors, there is a need for different forms of communication expressed. Professors provided examples in which their communication with the students in different formats simultaneously enabled greater transparency, making the relationship between those involved more trusting.

According to the report of the student, the fact they have, or do not have, better communication among the ones involved enabled the student to stay in the course longer. Another issue emphasized was the "shortening" of the educational chart, which enables better communication between those involved, because students/ customers can have easy access and the communication that they seek.

\section{Trust and loyalty: commitment to the relationship}

Trust and commitment are central in relationship marketing studies since they increase cooperation among partners and reduce the risk of an exchange for alternative partners (Morgan \& Hunt, 1994). Therefore, commitment in the relationship emerges between the institution and the student as a reason for the relationship between trust and loyalty, which, as mentioned by respondents, results from the reciprocity in the practices of the institution or professors and students. This was shown in the following comments:

"The commitment and involvement of the students have to be much deeper for this proposition of education. In the students that stay, the loyal ones, we were able to see this in detail." (Manager 8) 
One of the managers highlighted the importance of students' commitment and involvement because of the nature of the course. Thus, the student was deemed the main agent of loyalty. However, such a relationship was not perceived by the other groups interviewed, as follows.

"When the students get involved, they are committed, they will surely stay until the end of the course. [...] it also includes the practices of the institution, such as extension courses, internal activities, polls." (Professor 4)

It is observed that the interaction between professors and students provides a greater commitment of students while developing skills that are of high value, such as interactions in the virtual environment. It is necessary to interact by positioning themselves in the study that is being carried out in the course, which ends up changing not only the role of the professor but also that of the student:

"I noticed that the group alone started to commit more when they started to trust more in the institution and in the proposition (...)." (Student 1)

The commitment developed by the student after observing the same commitment of the others involved was evident in the report of daily examples given by the students interviewed. These examples emphasize the relevance of commitment to the action by the professors and different levels of the organization.

\section{Trust and loyalty: a reflex of the learning as a result}

The performance of the supplier regarding the factors common to their function, such as delivery, price/cost, service, and benefits, can change the future of the transactions since the competitors can supply the same potentialities (Doney \& Cannon, 1997). With the factors connected to performance and the benefits of the relationship based on experience as premises, it was observed that a specific group (professors) stressed situations that were linked to experiences related to student reports that highlighted positive points related to learning. These issues are addressed below.

"[...] a student once told me that she was more confident in her own capacity after the discipline was completed. Confidant regarding what was learned." (Professor 1)

The reports from the group of professors mentioned situations based on experiences prior to the development of disciplines or the courses, with the students as examples. This group emphasized that loyalty patterns were kept because the students perceived that the reflections on the experiences they had resulted in learning. 
Trust and loyalty: influence of the benevolence

According to Agustin and Singh (2005), trust is represented by the confidential belief of customers that a seller will deliver the services that they were promised. When it comes to belief in the delivery, the subjects responded that good faith from the institution was one of the reasons for the relationship between trust and loyalty.

"When the course sells something that it does not have, or something that is known to be changed soon, the fact of acting in bad faith regarding what was offered makes the student not become loyal to the institution." (Manager 5)

The reports of the managers emphasized the need for the HEI to develop the reasons linked with trust that are not only based on the students but also on the society as a whole. Related to this, Santos and Fernandes (2006) point out that uncertainty about the actions of the other party is a source of risk that contributes to the discontinuity of loyalty, which is evident in the reports of the managers. Moreover, the following manager underscores the importance of not only offering credibility but also maintaining it:

"[...] you have to believe so that this would happen. You have to have faith in this relationship. When this happens, the student stays until the end of the course." (Professor 8)

For the professors, good faith is already marked by the exchange of information between the students and the HEI. However, the students/customers exchange much information in the virtual environment and enroll in courses where they do not have contact with the professors or with the physical institution. An example of this is educational institutions that have campuses in different regions without having their own location.

"Not all students know where to search for information about the institution or the professors. (...).” (Student 2)

The answers from the group of students interviewed complement the answers of the previous groups. As highlighted by the last group, not all students know where to search for information about institutions or the professors. Morgan and Hunt (1994) include the attributes of consistency, competence, honesty, responsibility, good faith, and the integrity of the partners. 
Commitment and Loyalty: cognitive aspects of the relationship in the distance education

According to Fullerton (2003), customers must feel comfortable committing to the organization with which they do business. This comfort level must be the result of their interactions with and evaluations of the supplier of services. Thus, factors involving the cognitive part of the commitment and the results were present in the reports of the interviewees from the three groups. Such reports were related to the changes provided by the title of the course of the students connected to the following reasons:

"I see that a reason that is stronger than the cognitive reason is the need. The student stays because of some sort of need that he may have in the future: social, economic, personal (...)." (Manager 1)

The managers' reports pointed out that factors related to the calculative (cognitive) issues of the students with HEI as the most relevant reasons for the relationship between commitment and loyalty. Thus, according to the managers, social and economic aspects are factors related to the cognition of the individual while maintaining the relationship with the HEI:

"I see a very strong linking regarding the name of the institution in their resume and the benefit in the market because of this. I think that the reason is connected to issues of a better positioning of the students in the market, to improve the condition (...).” (Professor 4)

"(...) I believe that one of the reasons is the chance to improve their lives, financial, social condition and even internal, personal factors." (Student 4)

Answers to the questions about the reasons for the relationship between commitment and loyalty were related to the benefits that the results provide related to the goals and needs of the students. The group of professors, like the group of managers, pointed out that improvement in professional, economic, and personal conditions, as well as reference to the institution in the students' curriculum, make them stay in the institution. The students emphasized the fact that they realize that their peers enroll in courses because of the benefits that they will have after completing them. 


\section{Conclusion}

Companies from various segments invest in building long-term relationships to attract and retain customers, aiming to maintain these customers' loyalty while maintaining their profit margins. In this sense, understanding the factors that influence the background of loyalty and what surrounds them would help managers of educational institutions to better develop their relationship strategies with their students as well as open the possibility of theoretical advancement on the topic. This topic was chosen because the higher education market is increasingly competitive and, therefore, maintaining the student means maintaining a solid and predictable financial base for the future HEI activities.

Among the reasons found that lead to the relationship between perceived quality and loyalty, feelings of being welcomed, motivation, and credibility were emphasized by all groups and supported by the reference literature. Thus, initially, the proposition that the relationship between the constructs is motivated by intrinsic elements (feelings and motivations) and by the credibility of the HEI and the format of the course is highlighted.

The reasons found for the relationship between trust and loyalty were transparency, commitment, learning, and benevolence (goodwill). However, the answers related to these reasons had heterogeneous characteristics, which may be of concern for the educational institution because it may be delivering a value proposition at which the customers (students) are not aiming. For the reasons uncovered, the need for the student/customer to perceive actions that made them feel safe in the HEI with distance courses was central.

As regards the final relationship analyzed in this research, that is, commitment and loyalty, changes provided by the course titling were the reasons emphasized. As a proposition, it is suggested to consider the relationship between the result and the constructs in addition to the inclusion of the construct of trust since one of the results found to emerge from the relationship between trust and loyalty was the student's commitment.

The results revealed the importance of setting up cozy environments and allowing moments of exchange in the institutions' facilities. This can make a difference, considering competitiveness, for institutions that adopt specific strategies in their branches.

In addition, the results are key to the development of strategies involving investors and partners, since the offer of distance education courses involves innumerable situations that should be considered by institutions and that cannot be standardized, such as manuals and methodological processes.

Finally, the results show that the relationship marketing in educational institutions is a strong element of competition, especially in markets where there are many institutions and low differentiation of services is offered. 
After the development of the stages of this study, some limitations in the research were observed. The reasons presented in this study were derived from a qualitative interview with some limitations of generalization and measurement. In this sense, it is suggested that future research quantitatively verify the results found, which may be of value for the development of other studies.

\section{REFERENCES}

Agustin, C., \& Singh, J. (2005). Curvilinear Effects of Consumer Loyalty Determinants in Relational Exchanges. Journal of Marketing Research, 43, 96-108.

Ahu, S. (2005). The Effects of Soft and Hard Service Attributes on Loyalty: the mediating role of trust. Journal of Services Marketing, 19(2), 81-92.

Al-dweeri, R. M., Obeidat, Z. M., Al-Dwiry, M. A., Alshurideh, M. T., \& Alhorani, A. M. (2017). The Impact of E-Service Quality and E-Loyalty on Online Shopping: Moderating Effect of E-Satisfaction and E-Trust. International Journal of Marketing Studies, 9(2).

Anderson, E., Fornell, C., \& Lehmann, D. (1994). Customer satisfaction, market share, and profitability: Finding from Sweden. Journal of Marketing, 58(3), 5366.

Aurier, P., \& N'Goala, G. (2010). The differing and mediating roles of trust and relationship commitment in service relationship maintenance and development. Journal of the Academy of Marketing Science, 38, 303-325.

Aydin, S., \& Özer, G. (2005). The Analysis of Antecedents of Customer Loyalty in the Turkish Mobile Telecommunication Market. European Journal of Marketing, 39(7/8), 910-925.

Bergamo, F. V. (2008). A lealdade do estudante baseada na qualidade do relacionamento: Uma análise em instituições de ensino superior. Dissertação (Mestrado), Faculdade de Gestão de Negócios da Universidade Metodista de Piracicaba, Piracicaba.
Berry, L. L. (1983). Relationship Marketing. In L. Leonard, G. Berry, L. Shostack, \& G. Upah (Eds.), Emerging Perspectives on Services Marketing (25-28). Chicago, IL: American Marketing Association.

Boulding, W., Kalra, A., Staelin, R., \& Zeithaml, V.R. (1993). A dynamic process model of service quality: from expectations to behavioral intentions. Journal of Marketing Research, 3o(1), 7-27.

Castro, C. C., Dias, M. C., Pereira, L. L., \& Eckstein, L. C. (2003). Entre a qualidade e a satisfação: armadilhas e oportunidades na avaliação de cursos de Administração. In: Encontro Nacional dos Cursos de Graduação em Administração ENANGRAD XIV, Foz do Iguaçu.

Charalambous, A., Radwin, L., Berg, A., Sjovall, K., Patiraki, E., Lemonidou, C., \& Suhonen, R. (2016). An international study of hospitalized cancer patients' health status, nursing care quality, perceived individuality in care and trust in nurses: A path analysis. International journal of nursing studies, 61, 176-186.

Cheng, X., Fu, S., Han, Y., \& Zarifis, A. (2017). Investigating the individual trust and school performance in semivirtual collaboration groups. Information Technology \& People, 3o(3), 691-707.

Curran, J. M., \& Rosen, D. E. (2006). Student Toward College Courses: An Examination of Influences and Intentions. Journal of Marketing Education, 28, 135-148.

Dawkins, P., \& Reichheld, F. (1990). Customer retention as a competitive weapon. Directors \& boards, 14(4), 42. 
Doney, M., \& Cannon, J. (1997). An Examination of the Nature of Trust in Buyer-Seller Relationships. Journal of Marketing, 61(2), 35-51.

Eom, S. B., \& Ashill, N. (2016). The Determinants of Students' Perceived Learning Outcomes and Satisfaction in University Online Education: An Update. Decision Sciences Journal of Innovative Education, 14, 185-215.

Flick, U. (2009). Introdução à pesquisa qualitativa. Tradução Joice Elias Costa, 3rd. ed. Porto Alegre: Artmed.

Franco, S. R. K. (2003). Algumas reflexões sobre educação a distância. Revista Textual, SINPRO-RS.

Fullerton, G. (2003). When does commitment lead to loyalty? Journal of Service Research, 45(4), 333-344.

Garbarino, E., \& Johnson, S. M. (1999). The different roles of satisfaction, trust, and commitment in customer relationships. Journal of Marketing, 63(2), 70.

Geyskens, I., Steenkamp, J-B., Scheer, L. K., \& Kumar, N. (1996). The Effects of Trust and Interdependence on Relationship Commitment: A trans-Atlantic study. International Journal of Research in Marketing, 13(4), 303-317.

Grönroos, C. (2003). Marketing: gerenciamento e serviços. Rio de Janeiro: Elsevier.

Guimarães, R. T. (2005). Avaliação de marca das instituições de ensino superior no segmento de mestrado e doutorado em administração: Uma abordagem multivariada. Tese (Doutorado), Faculdade de Economia, Administração e Contabilidade, Universidade de São Paulo, São Paulo.

Gustafsson, A., Johnson M. D., \& Roos, I. (2005). The Effects of Customer Satisfaction, Relationship Commitment Dimensions and Triggers on Customer Retention. Journal of Marketing, 69(4). CRM Special Section.
Harris, L. C., \& Goode, M. M. H. (2004). The Four Levels of Loyalty and the Pivotal Role of Trust: a study of online service dynamics. Journal of Retailing, 8o(2), 139-158.

Hennig-Thurau, T., \& Klee, A. (1997). The Impact of Customer Satisfaction and Relationship Quality on Customer Retention - A Critical Reassessment and Model Development. Psychology \& Marketing, 14, 737-765.

Hennig-Thurau, T., Langer, M. F., \& Hansen, U. (2001). Modeling and managing student loyalty: an approach based on the concept of relationship quality. Journal of Service Research, 3(4).

Jaros, S. J., Jermier, J. M., Koehler, J. W., \& Sincich, T. (1993). Effects of continuance, affective, and moral commitment on the withdrawal process: An evaluation of eight structural equation models. Academy of Management Journal, 36(5), 951-995.

Kao, T-W., \& Lin, W. T. (2016). The relationship between perceived e-service quality and brand equity: A simultaneous equations system approach. Computers in Human Behavior, 57, 208-218.

Konrath, M. L. P., Tarouco, L. M. R., \& Behar, L. M. R. (2009). Competências: desafios para alunos, tutores e professores da EaD. CINTED-UFRGS Novas Tecnologias na Educação, 7(1).

Larán, J. A., \& Espinoza, F. S. (2004). Consumidores satisfeitos, e então? Analisando a satisfação como antecedente da lealdade. Revista de Administração Contemporânea, 8(2), 51-70.

Sanghyeop, L., Bee-Lia, C., \& Heesup, H. (2016). Role of service encounter and physical environment performances, novelty, satisfaction, and affective commitment in generating cruise passenger loyalty, Asia Pacific Journal of Tourism Research, 22(2), 131-146.

Lenka, U., Suar, D., \& Mohapatra, K. (2009). Service Quality, Customer Satisfaction, and Customer Loyalty in 
Indian Commercial Banks. Journal of Entrepreneurship, 18(1), 47-64.

Malhotra, N. K. (2006). Pesquisa de Marketing: uma Orientação Aplicada. (4th ed). Porto Alegre: Bookman.

Mathmann, F., Chylinski, M., Higgins, E. T., \& de Ruyter, K. (2016). Every step counts: When physical movement affects perceived value. Journal of Retailing and Consumer Services, 39, 279-285.

Miles, M. B., \& Huberman, A. M. (1994). Qualitative data analysis: an expanded sourcebook. California: Sage.

Morgan, R. M., \& Hunt, S. D. (1994). The Commitment-Trust Theory of Relationship Marketing. Journal of Marketing, 58(3), 20-38.

Moorman, C., Deshpandé, R., \& Zaltman, G. (1993). Factors Affecting Trust in Marketing Research Relationships. Journal of Marketing, 57, 81-101.

Oliver, R. L. (1999). Whence Consumer Loyalty? Journal of Marketing, 63, 33-44.

Parasuraman, A., Zeithaml V. A., \& Berry, L. L. (1985). A conceptual model of services quality and its implication for future research. Journal of Marketing, 49(4), 41-50.

Pan, Y., Sheng, S., \& Xie, F. T. (2012). Antecedents of customer loyalty: An empirical synthesis and reexamination. Journal of Retailing and Consumer Services, 19, 150-158.

Perin, M. G., Sampaio, C. H., Simões, C., \& Pólvora, R. S. (2012). Modeling antecedents of student loyalty in higher education. Journal of Marketing for Higher Education, 22(1), 101-116.

Rohden, S. F., Matos, C. A., \& Curth, M. O. (2016). Intenções de recompra e confiança do consumidor on-line. Revista de Ciências da Administração, 18(45), 9-24.

Sampaio, C. H., Perin, M. G., Simões, C., \& Kleinowski, H. (2012). Students' trust, value and loyalty: evidence from higher education in Brazil. Journal of Marketing for Higher Education, 22(1), 83-100.

Santos, C. P., \& Fernandes, D. (2006). Antecedentes e Consequências da Confiança do Consumidor no Contexto de Recuperação de Serviços. XXX Encontro da ANPAD, Salvador-BA.

Semprebon, E., \& Prado, P. H. M. (2016). A Influência do Poder no Relacionamento entre Consumidor e Marca. $R A C$, Rio de Janeiro, 2O(4), 389-411.

Sirdeshmukh, D., Singh, J., \& Sabol, B. (1992). Consumer Trust, Value, and Loyalty in Relational Exchanges. Journal of Marketing, 66(1), 15-23.

Taylor, S A., \& Hunter, G. (2003). An exploratory investigation into the antecedents of satisfaction, brand attitude, and loyalty within the (B2B) e-CRM Industry. Journal of Consumer Satisfaction, Dissatisfaction and Complaining Behavior, 16, 19-35.

Testa, M. G., \& Luciano, E.M. (2011). Exploring the Influence of Affiliation Motivation in the Effectiveness of WebBased Courses. International Journal of Web-Based Learning and Teaching Technologies, 6(4), 19-38.

Tinto, V. (1975). Dropout of Higher Education: A Theorical Synthesis of Recent Research. Review of Educational Research, 45, 89-125.

Tinto, V. (2007). Research and Practice of Student Retention: What Next? Journal of College Student Retention, 8(1), 1-19.

Villardi, R., \& Oliveira, E. G. (2005). Tecnologia na Educação: uma perspectiva sócio-interacionista. Rio de Janeiro: Dunya.

Wang, M-T., \& Holcombe, R. (2010). Adolescents' Perceptions of School Environment, Engagement, and Academic Achievement in Middle School. American Educational Research Journal, 47(3), 633-662.

Wetzels, M., Ruyter, K., \& Berglen, M. (1998). Marketing Service Relationships: The 
Role of Commitment. Journal of Business \& Industrial Marketing, 13(4/5), 406423.

Yin, R. K. (2005). Estudo de Caso: planejamento e métodos. Tradução Daniel Grassi. (3rd ed). Porto Alegre: Bookman.
Zeithaml, A. (1988). Consumer perceptions of price, quality and value: a means end model and synthesis of evidence. Journal of Marketing, 52(3), 2-22.

\section{ACADÉMIC AND PROFESSIONAL PROFILE OF THE AUTHORS}

Marcelo Curth. Doutor em Administração pela Universidade do Vale do Rio dos Sinos - UNISINOS, mestrado pela Universidade Católica do Rio Grande do Sul - PUC-RS, Pós-Graduado em Administração e Marketing pela Universidade Gama Filho e Pós-Graduado em Educação pela Faculdade SENAC-RS, graduação em Educação Física pela Universidade Luterana do Brasil - ULBRA e graduando em Administração pela UNISINOS. Os temas de interesse de pesquisa são comportamento do consumidor e marketing de relacionamento. Diretor das empresas Plation e Educare.

E-mails: m.curth1979@gmail.com - marcelocurth@feevale.br

Address:

510, Dr. Maurício Cardoso Avenue

Novo Hamburgo, RS

CEP 93510-235

Brazil

Claudio Hoffmann Sampaio. Doutor em Administração pela UFRGS (2000). Pós-doutor em Marketing pela University of Georgia (EUA). Bolsista de produtividade 1D do CNPq. Mestrado em Administração pela UFRGS (1993) e graduação em Administração pela UFRGS (1985). Coordenador do Programa de Pós-Graduação em Administração (PPGAd) da PUCRS. Os temas de interesse são orientações estratégicas, performance empresarial, inovação, comportamento do consumidor. Autor de artigos e livros nas áreas de marketing e de estratégia, consultor ad hoc de agências de fomento.

E-mail: csampaio@pucrs.br

Address:

6681, Ipiranga Avenue

Porto Alegre, RS

CEP 90619-900

Brazil 
Rafael Spolavori. Possui graduação em Administração de Empresas- ênfase Empreendedorismo- PUCRS (2006), Pós-Graduado em Mercado de Capitais e Finanças Corporativas - UFRGS (2009) e Mestrado em Economia- UNISINOS (2016). Professor com atuações em Núcleos Docentes Estruturantes (NDE), Comissões Próprias de Avaliação (CPA), coordenações de cursos de graduação e pósgraduação. Atualmente, dedica-se as áreas de pesquisa de finanças corporativas e organização industrial, consultorias empresariais nas áreas de processos e finanças. Diretor nas empresas Capacita e Educare.

E-mail: rafaelspolavori@gmail.com

Address:

435, Júlio de Castilhos Avenue

Porto Alegre, RS

CEP 90030-131

Brazil

Date of receipt: 19/06/2018

Date of acceptance: $26 / 06 / 2018$

Date of layout: $03 / 12 / 2018$ 